ISSN (Print) : : 1412-7601

ISSN (Online) : 2654-8712

Volume 5, No.1 Maret 2019

EKONOBIS

http://www.ekonobis.unram.ac.id

\title{
Analisis Pengalihan Fungsi Lahan Pertanian Menjadi Kawasan Terbangun Di Kecamatan Sekarbela Kota Mataram
}

\section{Emi Salmah, Titi Yuniarti, Tuti Handayani.} Universitas Mataram

\begin{tabular}{|c|c|}
\hline ARTICLE INFO & Received : 22Februari 2019; Accepted: 7 Maret 2019; Published: Maret 2019 \\
\hline $\begin{array}{l}\text { Keywords: } \\
\text { Changes in Land Use, } \\
\text { Kota Mataram }\end{array}$ & $\begin{array}{l}\text { ABSTRACT :The objectives to be achieved in this study are to, 1) Analyze what } \\
\text { factors cause changes in land use in the Sekarbeka District of Mataram City, 2). } \\
\text { Knowing how much influence the changes in land use occur on the economy of the } \\
\text { people in Sekarbela Subdistrict, Mataram City. The type of research used is } \\
\text { descriptive. The conclusion that can be taken is 1). the factors that influence the } \\
\text { conversion of agricultural land into a built area in Sekarbera District, Mataram } \\
\text { City are; legal factors, physical factors, socioeconomic factors, demographic } \\
\text { factors, 2). Conversion of agricultural land into a built area of the economy of the } \\
\text { Sekarbela District, Mataram City, affects: land prices, livelihoods, income, and } \\
\text { agricultural productivity. Of the four factors, the factors of land prices, } \\
\text { livelihoods, income and agricultural productivity are the most significant factors } \\
\text { affecting the economy of the community. }\end{array}$ \\
\hline $\begin{array}{l}\text { Kata Kunci: } \\
\text { Perubahan Pemanfaatan } \\
\text { lahan,Kota Mataram }\end{array}$ & $\begin{array}{l}\text { ABSTRAK:Tujuan yang ingin dicapai dalam penelitian ini adalah untuk, 1) Menganalisis } \\
\text { faktor-faktor apa yang menyebabkan terjadinya perubahan pemanfaatan lahan yang } \\
\text { berada di Kecamatan Sekarbeka Kota Mataram, 2). Mengetahui seberapa besar } \\
\text { pengaruh perubahan pemanfaatan lahan yang terjadi terhadap perekonomian } \\
\text { masyarakat di Kecamatan Sekarbela Kota Mataram. Jenis penelitian yang digunakan } \\
\text { adalah diskriptif. Kesimpulan yang dapat diambil adalah 1). faktor-faktor yang } \\
\text { mempengaruhi konversi lahan pertanian menjadi kawasan terbangun di Kecamatan } \\
\text { Sekarbera, Kota Mataram adalah; faktor hukum, faktor fisik, faktor sosial ekonomi, } \\
\text { faktor demografi, 2). Konversi lahan pertanian menjadi kawasan terbangun terhadap } \\
\text { perekonomian masyarakat Kecamatan Sekarbela, Kota Mataram, mempengaruhi } \\
\text { :harga lahan, mata pencaharian, pendapatan, dan produktivitas pertanian. Dari ke } \\
\text { empat faktor tersebut maka faktor harga lahan, mata pencaharian, pendapatan dan } \\
\text { produktivitas pertanian menjadi faktor yang paling signifikan mempengaruhi } \\
\text { perekonomian masyarakat. }\end{array}$ \\
\hline
\end{tabular}

Corresponding Author:

Alamat : Program Studi Ekonomi Pembangunan, Fakultas Ekonomi dan Bisnis, Universitas Mataram, Jln. Majapahit No. 62 Mataram.

e-mail: emisalmah@unram.ac.id 


\section{PENDAHULUAN}

Latar Belakang

Pertambahan penduduk yang relatif cepat, menyebabkan bertambahnya penyediaan tempat tinggal (permukiman) menjadi hal yang sangat mendesak. Di Indonesia, konversi lahan pertanian merupakan masalah krusial. Fenomena alih fungsi lahan pertanian ke non pertanian merupakan ancaman ketahanan pangan. Konversi lahan pertanian terus terjadi sampai tingkat mencemaskan dan menggangu. Secara umum, faktor eksternal dan internal mendorong konversi lahan pertanian.

Masalah konversi lahan dapat diatasi bila pemerintah daerah sangat ketat dalam hal penataan ruang.Pemerintah harus tegas dalam melarang pembangunan perumahan dan industri yang hendak menggunakan lahan di kawasan pertanian.Menjadikan sektor pertanian sebagai lapangan usaha yang menarik dan bergensi secara alami juga dapat mencegah terjadinya konversi lahan.Jika konversi terus terjadi tanpa terkendali, hal itu tidak saja menimbulkan persoalan ketahanan pangan, tapi juga lingkungan dan ketenaga kerjaan.

Kota Mataram merupakan salah satu kabupaten/kota yang ada di Provinsi Nusa Tenggara Barat (NTB) yang sekaligus merupakan Ibu Kota Provinsi NTB.Kota Mataram mencakup 6 (enam) kecamatan yang terdiri dari 50 Kelurahan. Luas wilayah berdasarkan data yang ada adalah $61.30 \quad \mathrm{KM}^{2}$ atau6.130 $\mathrm{Ha}$. Penduduk Kota Mataram berjumlah 450.226 jiwa dengan sex ratio 97 jiwa. Kepadatan penduduk 7.345 jiwa/ $\mathrm{km}^{2}$ ( Kota Mataram Dalam Angka, 2016 )

Kecamatan Sekarbela merupakan salah satu dari 6 kecamatan yang ada di Kota Mataram yang berada dibagian selatan, memiliki jumlah penduduk sebanyak 64.946 jiwa, terdiri dari 32.043 jiwa penduduk laki-laki dan 32.903 jiwa penduduk perempuan, dengan sex ratio 97, dengan tingkat kepadatan penduduk $6.293 \mathrm{jiwa} / \mathrm{km}^{2}$. ( Kecamatan Sekarbela Dalam Angka, Tahun 2016 )

Sejak dibuka jalan lingkar selatan, terjadi perubahan pada pemanfaatan lahan pertanian menjadi kawasan terbangun hal ini dapat dilihat dari adanya pertambahan rumah hunian dan pembangunan perumahan menggunakan jasa developer serta adanya pembangunan beberapa ruko atau mini market di daerah tersebut.Hal ini berdampak pada perekonomian masyarakat akibat pengaruh konversi lahan pertanian menjadi kawasan terbangun. 
|90Emi Salmah, Tity Yuniarti, Tuti Fandayani/Analisis Pengalihan Fungsi Lahan...

Dampak negative dari konversi lahan sawah tidak hanya berdampak pada penurunan hasil produksi pertanian, juga dapat menyebabkan hilangnya kesempatan kerja serta penurunan pendapatan petani penggarap dan juga buruh tani. Tak dapat diingkari bahwa untuk wilayah tropis maka fungsi sawah pada musim penghujan bukan sekedar lahan yang dipergunakan untuk budi daya padi, tetapi juga merupakan hamparan yang efektif untuk menampung kelebihan air limpasan.

Dalam kasus-kasus tertentu, konversi lahan sawah memang tak dapat dihindari.Sehubungan dengan permasalahan tersebut, tim peneliti mengangkat sebuah penelitian yang berjudul "Analisis Pengalihan Fungsi Lahan Pertanian Menjadi Kawasan Terbangun Di Kecamatan Sekarbela Kota Mataram"

\section{Rumusan masalah}

Rumusan permasalahan dalam penelitian adalah:

1. Faktor - faktor apa saja yang menyebabkan konversi lahan menjadi kawasan terbangun di Kecamatan Sekarbela Kota Mataram ?

2. Seberapa besar pengaruh konversi lahan pertanian menjadi kawasan terbangun terhadap perekonomian masyarakat Kecamatan Sekarbela kota Mataram?

\section{Tujuan dan Manfaat Penelitian}

Tujuan yang ingin dicapai dalam penelitian ini adalah untuk :

1. Mengidentifikasi faktor - faktor apa yang menyebabkan terjadinya perubahan pemanfaatan lahan yang berada di Kecamatan SekarbekaKota Mataram.

2. Mengetahui seberapa besar pengaruh perubahan pemanfaatan lahan yang terjadi terhadap perekonomian masyarakat di Kecamatan Sekarbela Kota Mataram.

Manfaat yang ingin dicapai dalam penelitian ini adalah :

1. Sebagai masukan yang bermanfaat dalam penyelenggaraan perubahan pemanfaatan lahan baik sebagai bahan referensi dan pertimbangan bagi pemerintah sebagai pengambilan keputusan bagi kebijaksanaan dan alternative penanganan permasalahan perkembangan Kecamatan Sekarbela, maupun kepada pihak masyarakat

2. Menjadi bahan kajian (referensi) bagi peneliti selanjutnya, khususnya yang memiliki keterkaitan dengan pengalihan fungsi lahan. 


\section{KAJIAN PUSTAKA}

\section{Pengertian kota}

Pengertian kota menurut Sabari Yunus (2005) terdapat enam perspective yang dapat digunakan sebagai dasar acuan dalam memahami pengertian kota yaitu : a) . Kota ditinjau dari segi yuridis, b) Kota ditinjau dari segi fisik morfologi, c) Kota ditinjau dari jumlah penduduk, d) Kota ditinjau dari kepadatan penduduk, d) Kota ditinjau dari fungsinya dalam suatu wilayah nodal . e) Kota ditinjau dari segi sosio-kultural. e) Aspek geografis, materealistis dibandingkan dengan daerah belakangnya dan f), Selanjutnya dikatakan bahwa kota merupakan tempat permukiman warga kota, tempat kerja, tempat hidup dan

Di mana dijelaskan pada pasal1 bahwa kawasan perkotaan adalah wilayah yang mempunyai kegiatan utama bukan pertanian dengan susunan fungsi kawasan sebagai tempat permukiman perkotaan, pemusatan dan distribusi pelayanan jasa pemerintahan, pelayanan sosial, dan kegiatan ekonomi.

\section{Pengertian Perubahan Fungsi Lahan} (konversi lahan)

Perubahan fungsi lahan adalah lahan yang mengalami alih fungsi, baik dari pertanian menjadi non pertanian. Pada umumnya masalah lahan di Indonesia, yaitu: 1).
Terjadinya kemunduran produktifitas yang tidak disertai usaha konversi lahan. 2).Terjadinya kemunduran produktifitas lahan sebagai akibat penggunaan yang tidak sesuai dengan kemampuan. 3) Terdesaknya lahan pertanian yang relative subur oleh jenis penggunaan lahan non pertanian di daerah perkotaan.

Perubahan penggunaan lahan (land use) yang cepat merupakan kenyataan banyak tempat di Indonesia. Sebagai perubahan penggunaan lahan yang optimum yang diharapkan karena menuju kepada penggunaan lahan yang berkesinambungan dan berwawasan lingkungan. Sebagian lainnya merupakan perubahan atau penurunan lahan yang tidak terkendali dan mengarah pada kerusakan lahan.

\section{Konsep pola pemanfaatan lahan}

Dalam usaha untuk mendapatkan gambaran secara menyeluruh mengenai pola pemanfaatan lahan sesuatu daerah, langkah pertama yang harus ditempuh ialah mengadakan penyederhanaan sebutan dari jenis-jenis pemanfaatan lahan yang beraneka ragam itu dengan membuka klasifikasi penggunaan lahan secara sistematis.

Mengemukakan berbagai masalah yang dihadapi dalam penggunaan lahan di Indonesia menunjukkan bahwa masalah 
|92Emi Salmah, Tity Yuniarti, Tuti Handayani/Analisis Pengalihan Fungsi Lahan...

ini perlu diupayakan alternative pemecahannya.

Proses perubahan polapemanfaatan lahan dapat diikuti dengan membangdingkan potret udara atau citra satelit dari berbagai tahun, dari perbandingan itu dapat dilihat bertambahnya luas daerah permukiman dan berkurangnya lahan pertanian.

\section{Faktor-Faktor Yang Mempengaruhi} Konversi Lahan

Faktor-faktor yang paling berpengaruh terhadap penggunaan lahan dapat disebutkan secara berurutan adalah faktor institusi/hukum, faktor fisik, faktor ekonomi dan faktor kependudukan.

Faktor-faktor sosial ekonomi akan menjadi lebih penting pada saat akan menentukan penggunaan lahan optimum. Faktor-faktor sosial ekonomi tersebut meliputi letak lahan dalam hubungannya dengan lokasi pasar, transportasi, permukiman dan aktivitas manusia lainnya. Di samping itu kebijaksanaan pemerintah juga merupakan salah satu faktor penting yang perlu di pertimbangkan dalam penentuan penggunaan lahan.

\section{METODE PENELITIAN}

Lokasi dan Waktu Penelitian
Penelitian ini berlokasi di Kecamatan Sekarbela, Kota Mataram. Alasan mengambil lokasi sebagai obyek penelitian, karena di Kota Mataram Khususnya di Kecamatan Sekarbela telah terjadi banyak perubahan pengalihan fungsi lahan pertanian menjadi lahan terbangun.

\section{Jenis Data}

Jenis data dapat dibedakan menjadi : Data kualitatif dan Kuantitatif.

\section{Sumber data}

Data primer yaitu data yang diperoleh melalui pengamatan langsung dilapangan dan Data sekunder, dapat berupa literatur, dokumen dll.

\section{Teknik Pengumpulan Data}

Untuk mendapatkan data yang dibutuhkan, metode pengumpulan data yang digunakan dalam penelitian yaitu: a). Observasi, b) Kuisioner, c). Dokumentasi.

\section{Populasi dan Sampel}

1. Populasi; Populasi dalam penelitian ini adalah masyarakat Kecamatan Sekarbela yang berjumlah 64.946 jiwa.

2. Sampel; Teknik penarikan sampel dengan sampel acak (sample random). Jumlah responden sebanyak 25 orang, tiap Kelurahan diwakili oleh 5 orang dari berbagai profesi.

\section{Metode Analisis Data}


Metode analisis yang dipergunakan dalam menganalisis masalah yakni :

1. Penentuan faktor-faktor yang mempengaruhi konversi lahan menjadi kawasan terbangun

a. Analisis Kualitatif dengan menggunakan metode evaluatif.

Metode evaluatif digunakan untuk menilai sejauhmana tingkat kesesuaian perubahan pemanfaatan lahan yang terjadi saat ini dengan arahan rencana pemanfaatan lahan (RDTR Kawasan) yang ada.

b. Tabulasi Silang (Crosstabulation)

Data yang terjaring melalui hasil quesioner, diolah dan dianalisis dengan metode deskriptif kualitatif-kuantitatif dengan menggunakan pendekatan tabulasi silang (Crosstabulation).

\section{Pengaruh konversi lahan pertanian} menjadi lahan terbangun terhadap perekonomian masyarakat

Untuk mendapatkan gambaran mengenai rumusan masalah 2 yang terkait dengan pengaruh konversi lahan pertanian menjadi lahan terbangun terhadap perekonomian masyarakat, maka digunakan teknik analisis regresi linier, dimana teknik analisis regresi linier ini untuk mengetahui sejauhmana pengaruh konversi lahan pertanian ini terhadap perekonomian masyarakat di Kecamatan Sekarbela.

\section{ANALISIS DAN PEMBAHASAN}

\section{Gambaran Umum Kota Mataram}

1. Geografi, Administrasi wilayah dan Penduduk

Kota Mataram adalah salah satu dari 10 kabupaten / kota dalam wilayah Provinsi Nusa Tenggara Barat yang terletak di Pulau Lombok. Kota Mataram memiliki luas $61,30 \mathrm{~km}^{2}$ terdiri dari 6 kecamatan dengan jumlah kelurahan sebanyak 50. Kecamatan yang terluas adalah Selaparang yaitu $10,77 \mathrm{Km}^{2}$ sedangkan yang terkecil adalah Kecamatan Ampenan dengan luas $9,460 \mathrm{Km}^{2}$.

Tabel 1 Luas wilayah Kecamatan dan Jumlah Kelurahan di

Kota Mataram, Tahun 2016

\begin{tabular}{|c|l|r|r|r||}
\hline No & Kecamatan & Luas $\mathbf{( k m}^{\mathbf{2}} \mathbf{1}$ & persentasi & Jumlah Kelurahan \\
\hline 1 & Ampenan & 946 & 15,43 & 10 \\
\hline 2 & Sekarbela & 1.032 & 16,84 & 5 \\
\hline 3 & Mataram & 1.076 & 17,55 & 9 \\
\hline 4 & Selaparang & 1.077 & 17,57 & 9 \\
\hline 5 & Cakra Negara & 967 & 15,77 & 10 \\
\hline 6 & Sandubaya & 1.032 & 16,84 & 7 \\
\hline \multicolumn{2}{|l|}{ Kota Mataram } & 6.130 & 100,00 & 50 \\
\hline
\end{tabular}


194Emi Salmah, Tity Yuniarti, Tuti Handayani/Analisis Pengalihan Fungsi Lahan...

Penduduk Kota Mataram Tahun 2016 berjumlah 450.226 jiwa yang terdiri dari laki laki 222.596 jiwa dan Perempuan berjumlah 227.630 jiwa dengan sex ratio 98, artinya dari 100 perempuan terdapat 98 jiwa laki laki. Kecamatan yang terbanyak penduduknya adalah Kecamatan Ampenan berjumlah 87.746 jiwa dan yang tersedikit penduduknya adalah Kecamatan Sekarbela sebunKøndisi Fisik dasar Kecamatan Sekarbela 64.946 jiwa.

\section{Penggunaan Lahan}

Dari data yang dikumpulkan kita dapat melihat bahwa ada beberapa lahan/ tanah yang penggunaannya bertambah, berkurang dan ada juga yang tetap. Lahan yang makin lama semakin berkurang adalah lahan pertanian, pada Tahun 2012 lahan pertanian seluas $2.819,42 \mathrm{Ha}$ berkurang menjadi 2.773,63 $\mathrm{Ha}$, mengalami penurunan sebesar $45,97 \mathrm{Ha}$ atau sebesar 1,65 persen.

Sejalan dengan penelitian ini, kawasan pemukiman mengalami peningkatan dari 2.352,1 Ha pada Tahun 2012 meningkat menjadi 2.425, Ha pada Tahun 2016, berarti mengalami peningkatan sebesar $74,5 \mathrm{Ha}$ atau 3,17 persen.

2.Gambaran umum Kecamatan Sekarbela a. Geografis dan administrasi
Kecamatan Sekarbela terdiri dari 5 kelurahan yaitu : Kelurahan Jempong Baru, Tanjung Karang, Karang Pule, Tanjung Karang Permai dan Kelurahan Kekalik Jaya semuanya berstatus Definitif, dengan luas wilayah administrasi pemerintahan $10,319 \mathrm{Km}^{2}$. Topografi Kecamatan Sekarbela adalah dataran rendah dan pantai.
1. Topografi

Kecamatan Sekarbela yang terdiri dari 5 Kelurahan yang terdiri dari kawasan pantai dan dataran rendah. Sebagian besar wilayah yang ada dapat digunakan untuk usaha pembangunan dan pengembangan Kota Mataram sejak dibukanya jalan lingkara selatan.

\section{Penggunaan Lahan}

Penggunaan lahan kota akan terus mengalami perubahan seiring dengan perkembangan dan peningkatan berbagai aktifitas manusia diatasnya. Hal tersebut terjadi pada Kecamatan Sekarbela yang mengalami perubahan penggunaan lahan.

\section{Kependudukan}

Dari tabel 2 dapat diketahui bahwa jumlah penduduk di Kecamatan Sekarbela pada Tahun 2016 berjumlah 64.946 jiwa terdiri dari penduduk laki laki berjumlah 32.043 
jiwa atau 49,34 persen dari jumlah penduduk dan perempuan berjumlah 32.903 jiwa atau 50,64 persen dengan sex ratio 97, maksudnya dari 100 perempuan terdapat 97 jiwa laki laki.
Kepadatan penduduk di Kecmatan Sekarbela sebanyak 6.293 jiwa, artinya $1 \mathrm{Km}^{2}$ dihuni oleh penduduk sebanyak 6.293 jiwa, ini dikategorikan kepadatan ringan.

Tabel 2Jumlah Penduduk, Luas Wilayah dan Kepadatan Penduduk di Kecamatan Sekarbela Tahun 2016

\begin{tabular}{|c|c|c|c|c|c|c|c|}
\hline \multirow{2}{*}{ No } & \multirow{2}{*}{ Kelurahan } & \multirow{2}{*}{$\begin{array}{l}\text { Luas } \\
\left(\mathrm{Km}^{2)}\right.\end{array}$} & \multicolumn{2}{|c|}{$\begin{array}{c}\text { Jumlah } \\
\text { Penduduk }\end{array}$} & \multirow{2}{*}{$\begin{array}{c}\text { Jumlah } \\
\text { penduduk } \\
\text { (Jiwa) }\end{array}$} & \multirow{2}{*}{$\begin{array}{l}\text { Kepa } \\
\text { datan } \\
\text { ( jiwa ) }\end{array}$} & \multirow{2}{*}{$\begin{array}{c}\text { Sex } \\
\text { Ratio }\end{array}$} \\
\hline & & & $\begin{array}{l}\text { Laki } \\
\text { (Jiwa ) }\end{array}$ & $\begin{array}{l}\text { Prpuan } \\
\text { ( jiwa ) }\end{array}$ & & & \\
\hline 1 & Jempong Baru & 4,662 & 7.150 & 7.611 & 14.761 & 3.173 & 94 \\
\hline 2 & Tanjung Karang & 2,57 & 4.550 & 4.328 & 8.878 & 3.454 & 105 \\
\hline 3 & Karang Pula & 1,067 & 7.397 & 7.263 & 14.660 & 13.739 & 102 \\
\hline 4 & Tj. Karang Permai & 0,678 & 4.080 & 3.999 & 8.079 & 11.916 & 102 \\
\hline 5 & Kekalik Jaya & 1,352 & 8.866 & 9.702 & 18.568 & 13.734 & 91 \\
\hline & Jumlah & 10,32 & 32.043 & 32.903 & 64.946 & 6.293 & 97 \\
\hline
\end{tabular}

Sumber :Kecamatan Sekarbela dalam angka Tahun 2017

pesat hal ini dapat dilihat dari

Kalau kita perhatikan Sex Ratio ada 3 ( tiga

) kelurahan yang mempunyai angka sex ratio di atas 100 , yaitu Kelurahan Karang Pula, Tanjung Karang Permai dan Kelurahan Tanjung Karang, ini menunjukkan bahwa jumlah penduduk

laki laki lebih banyak dibandingkan penduduk perempuan.

\section{Analisa Pengembangan Kota}

\section{Berdasarkan RTRW}

Kota Mataram setiap tahunnya mengalami perkembangan yang cukup bertambahnya kawasan perdagangan, pemukiman, perkantoran dan fasilitas fasilitas umum lainnya bagi masyarakat.

Rencana Tata Ruang Wilayah (RTRW) Kota Mataram pengembangannya lebih mengarah ke arah selatan, terutama kearah Jempong Baru, karena lahan yang tersedia masih banyak, sementara kalau kearah utara sudah tidak memungkinkan, karena lahan sudah tidak tersedia lagi. Berikut akan disajikan penilaian masyarakat tentang keterkaitan antara arah pengembangan dengan RTRW 
|96Emi Salmah, Tity Yuniarti, Tuti Fandayani/Analisis Pengalihan Fungsi Lahan...

Tabel 3Penilaian Masyarakat Tentang Keterkaitan Antara Arah Pengembangan

Dengan RTRW di Kecamatan Sekarbela Tahun 2016

\begin{tabular}{|c|c|c|c|c|}
\hline \multirow[t]{2}{*}{ No } & \multirow[t]{2}{*}{ Kelurahan } & \multicolumn{3}{|c|}{$\begin{array}{c}\text { Penilaian Masyarakat Tentang Keterkaitan Antara } \\
\text { Arah Pengembangan Dengan RTRW }\end{array}$} \\
\hline & & Berpengaruh & $\begin{array}{l}\text { Kurang } \\
\text { Berpengaruh }\end{array}$ & $\begin{array}{l}\text { Tidak } \\
\text { Berpengaruh }\end{array}$ \\
\hline 1 & Jempong Baru & 3 & 1 & ratan \\
\hline 2 & Tanjung Karang & 4 & 1 & \\
\hline 3 & Karang Pule & 3 & 2 & \\
\hline 4 & Tjg Karang Permai & 3 & 1 & 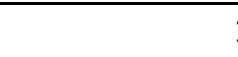 \\
\hline 5 & Kekalik Jaya & 4 & 2 & \\
\hline & Jumlah & 16 & 7 & 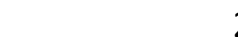 \\
\hline
\end{tabular}

Sumber : Hasil Survey di Kecamatan Sekarbela 2017

Berdasarkan hasil analisis yang telah

\section{Analisis Perubahan Penggunaan Lahan}

Pada Tahun 2016 penggunaan lahandi Kecamatan Sekarbela, diperuntukkan untuk perumahan dan pekarangan, fasilitas umum, perkantoran, perdagangan dan areal persawahan, jalan dan penggunaan lahan lainnya. Perubahan penggunaan lahan yang paling dominan di Kecamatan Sekarbela dari tahun 2012 hingga tahun 2016 yaitu lahan sawah. Areal sawah dan persawahan merupakan

lahan yang terbesar yang berubah fungsi menjadi lahan permukiman. dilakukan di atas, perkembangan perubahan penggunaan lahan di Kecamatan Sekarbela Tahun 2012 masih didominasi oleh kegiatan lahan kering dan lahan /pertanian dengan persentase masing-masing $49,88 \%$ dan $25,03 \%$ dan pada tahun 2016 mengalami penurunan, dimana penggunaan lahan kering dan lahan pertanian berubah menjadi 40,31\% dan 23,33\%. Sedangkan untuk lahan permukiman mengalami peningkatan, yakni pada tahun 2012 sekitar 396 ha (13,39\%) dan tahun 2016 sekitar 456 ha $(15,42$ persen), terjadi peningkatan sebesar $60 \mathrm{Ha}$.

Tabel 4Perkembangan Penggunaan Lahan Di Kecamatan Sekarbela Tahun 20012-2016

\begin{tabular}{|l|l|l|l|l|}
\hline No & Jenis & Tahun 2012 & Tahun 2016 & Perubahan \\
\hline \hline
\end{tabular}




\begin{tabular}{|c|c|c|c|c|c|c|}
\hline & $\begin{array}{c}\text { Penggunaan } \\
\text { Lahan }\end{array}$ & $\begin{array}{l}\text { Luas } \\
\text { (ha) }\end{array}$ & $\begin{array}{c}\text { Persentase } \\
\text { (\%) }\end{array}$ & $\begin{array}{l}\text { Luas } \\
\text { (ha) }\end{array}$ & $\begin{array}{c}\text { Persentase } \\
\text { (\%) }\end{array}$ & $\begin{array}{l}\text { Luas } \\
\text { (ha) }\end{array}$ \\
\hline 1 & $\begin{array}{l}\text { Lahan } \\
\text { pertanian } \\
\text { (sawah) }\end{array}$ & 740 & 25,03 & 690 & 23,33 & -50 \\
\hline 2 & $\begin{array}{l}\text { Lahan Kering } \\
\text { (Tegal, kebun, } \\
\text { hutan rakyat, } \\
\text { dan rawa) }\end{array}$ & 1475 & 49,88 & 1192 & 40,31 & -283 \\
\hline 3 & Permukiman & 396 & 13,39 & 456 & 15,42 & +60 \\
\hline 4 & Lainnya & 346 & 11,69 & 646 & 21.83 & +318 \\
\hline & Jumlah & 2957 & 100 & 2957 & 100 & 300 \\
\hline
\end{tabular}

Sumber: Hasil Analisis, Tahun 2017

Untuk dapat mengontrol perubahan penggunaan lahan ini diperlukan adanya suatu pola penggunaan lahan yang diharapkan dapat menjadi pedoman penggunaan lahan yakni Rencana Tata Ruang Wilayah Kawasan Perkotaan RTRWKP ) Kecamatan Sekarbela. Adanya pedoman tersebut diharapkan dapat meningkatkan efesiensi perubahan penggunaan lahan sehingga memberikan hasil yang optimal dan berdaya guna terhadap perubahan yang terjadi. Agar nantinya tidak terjadi kesemrawutan kotadalam artian pedoman tersebut berisikan aturan-aturan yang dibuat oleh pemerintah daerah yang kemudian disepakati oleh masyarakat, sehingga apabila perubahan yang terjadi tidak sesuai dengan pedoman rencana yang telah dibuat, dapat diberlakukan pemberian sangsi kepada yang melanggarnya. Peraturan dibuat dengan maksud masyarakat mengetahui bahwa perubahan yang tidak sesuai rencana akibatnya dapat menimbulkan berbagai macam permasalahan baru seperti kemacetan lalu lintas dan banjir.

\section{Faktor - Faktor Penyebab Terjadinya Konversi Lahan Pertanian Menjadi Kawasan Terbangun.}

Untuk rumusan masalah pertama yakni faktor penyebab terjadinya konversi lahan pertanian menjadi kawasan terbangun di Kecamatan Sekarbela, yaitu :

\section{a. Faktor hukum}

Kecamatan Sekarbela dengan luas 6.130 ha, dimana luas lahan 
permukiman pada tahun 2012 adalah 15,42 ha merupakan salah satu pendapatan atau asset pemerintah daerah (PEMDA) setempat, dimaksudkan lahan maupun bangunanbangunan yang ada di Kecamatan Sekarbela utamanya permukiman, dalam hal pembangunan awal dikenakan Izin Mendirikan Bangunan (IMB).

Kecamatan Sekarbela dengan adanya pergeseran perubahan fungsi lahan, tidak terlepas dari adanya pihakpihak terkait, yang terlibat dalam hal perubahan fungsi yang memberikan izin melakukan pembangunan maupun dari kesadaran masyarakat sendiri.Utamanya dalam hal pembangunan yang tidak sesuai dengan fungsi dan status kawasan tersebut, ditunjang dengan masyarakat yang berpenghasilan tinggi, melakukan pembangunan sarana pertokoan yang merupakan salah satu tuntutan kebutuhan dalam masyarakat yang bermukim disekitar wilayah permukiman.

Implikasi dari masih rendahnya sarana penunjang seperti yang tertera di atas serta adanya pihak-pihak terkait yang terlibat dalam hal perubahan penggunaan lahan kaitannya dengan fungsi kawasan, maka bermunculan secara alamiah pula warung, toko yang sebelumnya hanya bersifat sementara, lambat laun perubahan tersebut menjadi permanen, sehingga sebagian masyarakat yang ekonomi menengah keatas ikut memanfaatkan peluang ini menjadi matapencaharian pokok.

Kebijakan pemerintah dalam hal penentuan lahan sangat berengaruh terhadap perubahan pemanfaatan lahan.Berdasarkan hasil analisis dan survey lapangan, diketahui terjadi perubahan penggunaan lahan, perubahan yang terjadi berjalan sesuai dengan peruntukannya. Akan tetapi saat ini lahan untuk permukiman semakin meningkat dan diiringi dengan pembangunan fasilitas-fasilitas pendukung sarana permukiman tersebut yang cukup besar merubah areal persawahan menjadi perumahan dengan pertimbangan lahan persawahan di daerah Kecamatan Sekarbela, padahal sawah yang ada di Kecamatan Sekarebela adalah persawahan dengan sistem irigasi tehnis.

Dengan dipindahkannya kawasan perkantoran pada Kelurahan Jempong Baru, sehingga RTRW pada Kelurahan Jempong Baru mengalami perubahan, 
dengan demikian perubahan banjir), dan 20 persen responden penggunaan fungsi lahan ini terjadi responden menjawab tidak (lokasi sering setelah ditetapkannya Kelurahan Jempong Baru sebagai kawasan perkantoran banjir), dan yang menjawab kadangkadang (lokasi kadang kadang banjir) ada 16 persen responden. Maka dapat

b. Faktor fisik

\section{Topografi dan kemiringan lereng}

Berdasarkan kondisi topografi / kemiringan lereng lahan pada Kecamatan Sekarbela yang relatif datar, sehingga kondisi topografi bukan merupakan hambatan dalam mengembangkan kawasan permukiman dan mengembangkan kawasan ini sebagai kawasan terbangun perkotaan.

\section{Hidrologi}

Keadaan hidrologi pada umumnya masyarakat di Kecamatan Sekarbela memakai PAM, sumur gali dan sumur pompa. Hal ini juga didukung oleh adanya 2 sungai yang terdapat pada Kecamatan Sekarbela, yakni Sungai Dodokan yang mengalir di Kelurahan Kekalikn Jaya dan Sungai Erat Tengak, mengalir melewati Kelurahan Karang Pula dan Tanjung Karang. Sebagian besar masyarakat di Kecamatan Sekarbela memanfaatkan air bersih dari jaringan PDAM.

Berdasarkan hasil survey
menunjukkan bahwa 64 persen
responden menjawab ya

disimpulkan bahwa konversi lahan pertanian menjadi kawasan terbangun terhadap hidrologi tidak berpengaruh di Kecamatan Sekarbela.

\section{Kondisi lingkungan di Kecamtan Sekarbela}

Kecamatan Sekarbela terdiri dari dari 5 Kelurahan yaitu Kelurahan Jempong Baru, Tanjung Karang. Karang Pula, Tanjung Karang Permai dan Kelurahan Kekalik Jaya. Menurut hasil survey dan pengamatan di Kecamatan Sekarbela tepatnya di Kelurahan Kekalik Jaya dan Kelurahan Karang Pule, merupakan lokasi pemukiman yang terpadat, karena merupakan Kelurahan yang menjadi cikal bakal munculnya Kecamatan Sekarbela, dan kebanyakan masyarakatnya adalah penduduk asli yang selalu hidup berdampingan ( tidak mau jauh ) dengan sanak keluarganya / familinya,walaupun berhimpitan.

\section{Sarana dan prasarana}

\section{a. Prasarana :}

\section{Jaringan jalan}

Jaringan jalan yang ada di Kecamatan Sekarbela saat ini kondisinya sudah 
|100Emi Salmah, Tity Yuniarti, Tuti Handayani/Analisis Pengalihan Fungsi Lahan...

sangat baik, namun masih ada jalan yang kondisinya jalan berupa jalan kerikil sepanjang $0,998 \mathrm{Km}$ yang ada di Kelurahan Jempong Baru.

\section{Jaringan drainase}

Prinsip dasar pembuangan/pengaliran air hujan (permukaan) adalah bahwa air harus secepat mungkin dibuang dan secara terus menerus (continue), serta dilakukan seekonomis mungkin. Dengan demikian, penyediaan saluran pembuangan merupakan usaha untuk mengatasi masalah banjir atau genangan air pada suatu kawasan.Pembuangan dan / atau pengaliran air permukaan merupakan usaha preventif (pencegahan) untuk mencegah terjadinya banjir atau genangan air yang dapat menimbulkan genangan yang bermuara pada timbulnya penyakit bagi manusia. Berkaitan dengan air hujan apa bila tidak disalurkan dengan cepat akan menimbulkan masalah genangan/ banjir.

Cepat atau lambatnya pengaliran air hujan tergantung pada sistem dan bentuk drainase yang ada. Jaringan drainase yang ada di Kecamatan Sekarbela adalah menggunakan saluran drainase terbuka yang mengikuti ruas jalan, akan tetapi tidak semua ruas jalan seperti di Jalan Sultan Kaharuddin ( Kelurahan Karang Pule ada yang masih menggunakan drainase yang permanen, tanah, bahkan ada yang tidak memiliki jaringan drainase. Serta pengalihan fungsi Kali Erat Tengak yang ada dibelakang Kelurahan Karang Pula, menjadi drainase utama/kanal diakibatkan terjadinya pendangkalan sungai.

\section{Jaringan air bersih}

Prasarana dan sarana air bersih merupakan suatu kebutuhan yang harus dikembangkan secara berkelanjutan untuk dapat melayani kebutuhan penduduk akan air minum yang merupakan kebutuhan primer dalam kehidupan manusia Pelayanan air bersih saat ini masih belum optimal dalam artian belum semua jaringan jalan yang ada terdapat saluran air bersih, demikian pula belum semua rumah tangga dapat memanfaatkan air bersih yang pelayanannya dilakukan oleh PDAM, sehingga sebagian penduduk masih menggunakan sumur gali dan sumur pompa

\section{Alat Komuniksi}

Alat Komunikasi merupakan alat pembawa pesan yang paling cepat, 
mudah dan murah serta terjamin keamanannya.Karakter alat komunikasi ini menjadikannya sebagai suatu kebutuhan penting dalam aktivitas masyarakat perkotaan yang kegiatannya bertumpu pada kegiatan ekonomi.

Kebutuhan prasarana telepon adalah pengembangan sistem jaringan yang mengikuti ruas jalan yang dilngkapi sarana pendukung seperti rumah kabel, kotak, pembagi dan telepon umum. Namun seiring dengan perkembangan teknologi informasi, maka di Kecamatan Sekarbela sudah ada prasarana telephon seluler yaitu tower penerima dan pendistribusi agar sistem komunikasi penduduk pengguna telephon seluler yang lebih praktis dan ekonomis, sedangkan untuk jaringan yang tersedia adalah semua jaringan Simpati, $A S, X L$, kartu Hallo dll.

\section{Jaringan listrik}

Listrik merupakan salah satu kebutuhan primer, karena dengan listrik penduduk dapat meningkatkan produktivitasnya, misalnya dengan adanya penerangan lampu listrik penduduk dapat belajar pada malam hari, ronda/siskamling malam hari termasuk keamanan perjalanan di malam hari, adanya listrik penduduk dapat mengefisiensikan pekerjaan kantor dengan penggunaan komputernisasi dan peralatan lainnya yang menggunakan listrik. Selain itu, dengan adanya listrik dapat mempermudah/ mengifisienkan waktu masyarakat dalam melakukan beberapa kegiatan/pekerjaan rumah tangga, seperti alat-alat rumah tangga berkaitan dengan masak memasak (sambil menghubungkan dengan listrik pekerjaan lain dapat dilakukan).

Untuk mendukung hal-hal tersebut di atas, maka sangat dibutuhkan akan adanya pelayanan kelistrikan melalui pengembangan jaringan di semua ruas jalan yang ada (melayani di udara atau tertanam dalam tanah). Penyediaan penerangan jalan, peremajaan tiang listrik dan penambahan daya listrik untuk memenuhi kebutuhan seluruh kegiatan perkotaan.Daya listrik yang bersumber dari PLTD masih sangat dibutuhkan sebagai cadangan persediaan listrik.

\section{b. Sarana}

\section{Fasilitas pemerintahan}

Berdasarkan hasil survey dan data yang diperoleh. Fasilitas perkantoran pemerintahan di Kecamatan Sekarbela terdapat kantor Camat, kompleks 
|102Emi Salmah, Tity Yuniarti, Tuti Handayani/Analisis Pengalihan Fungsi Lahan...

Kantor Dinas, dinas-dinas terkait, kantor polisi, kantor kelurahan di tiap kelurahan yang melayani skala kecamatan, serta balai-balai pertemuan.

\section{Fasilitas perdagangan}

Berdasarkan hasil survey dan data yang diperoleh, fasilitas perdagangan di Kecamatan Sekarbela terdiri dari pasar, dan kios / warung. Di Kecamatan Sekarbelaa terdapat 1 pasar tradisional yang terletak di Kelurahan Tanjung Karang yakni Pasar Perumnas

\section{Fasilitas pendidikan}

Fasilitas pendidikan yang ada di Kecamatan Sekarbela dari TK, SD/ibtidayah, SMP/tsanawiyah, SMA/aliyah, dan perguruan tinggi. Dimana SD lebih banyak dibandingkan jenjang pendidikan lainnya seperti TK yang jumlahnya sebanyak 14, SD sebanyak 22, SMP sebanyak 9, sedangkan SMA sebanyak 7 dan untuk perguruan tinggi sebanyak 4 .

\section{Fasilitas Kesehatan}

Saat ini, sarana kesehatan di Kecamatan Sekarbela terdiri dari 2 unit puskesmas yang ada di Kelurahan Tanjung Karang dan Kelurahan Jempong Baru, 2 unit Ponpedes serta
55 unit posyandu yang tersebar di tiap Kelurahan di Kecamatan Sekarbela.

\section{Fasilitas Peribadatan}

Standar perencanaan untuk kebutuhan fasilitas peribadatan menurut keputusan pemerintah No.534/KPTS/M/2001 adalah terdapat 1 unit tempat ibadah dengan penduduk pendukung minimal 2.500 orang, dengan luas $300 \mathrm{~m}^{2}$, kriteria lokasi tergantung kondisi setempat.

Di Kecamatan Sekarbela saat ini berpenduduk sebanyak 64.946 jiwa, yang menganut 4 agama yaitu islam, Kristen, Hindu dan Budha yang penduduknya mayoritas islam. Di Kecamatan Sekarbela terdapat fasilitas peribadatan terdiri dari 44 unit mesjid yang tersebar di seluruh Kelurahan di Kecamatan Sekarbela, 36 unit langgar/mushalla yang tersebar di beberapa kelurahan, Gereja 1 unit ada di Kelurahan Kekalik Jaya dan 6 unit pura.

Sarana peribadatan yang ada di Kecamatan Sekarbela telah sesuai dengan kebutuhan dan skala pelayanannya cukup baik, karena jumlah sarana peribadatan cukup banyak sehingga penduduk dapat melaksanakan ibadah sesuai dengan kepercayaan masing-masing.

\section{Faktor sosial ekonomi}




\section{a. Mata pencaharian}

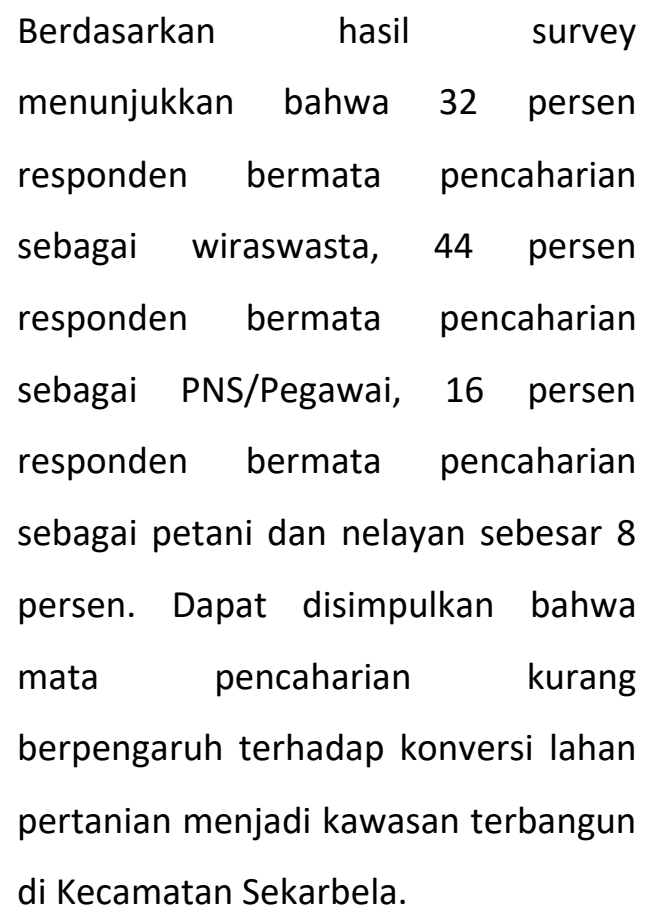

\section{b. Harga lahan}

Berdasarkan hasil survey menunjukkan bahwa 25 persen responden menjawab dibawah $\mathrm{Rp}$ 100.000.000, responden yang menjawab antara Rp 100.000.000- Rp 150.000.000, 52 persen dan 28 persen responden menjawab $<\mathrm{Rp}$ 200.000.000. Dapat disimpulkan bahwa konversi lahan pertanian menjadi kawasan terbangun berpengaruh terhadap harga lahan di Kecamatan Sekarbela.

\section{c. Produktivitas pertanian}

Berdasarkan tabel hasil survey menunjukkan bahwa 67 persen responden menjawab ya (berpengaruh) dan 33 persen responden menjawab tidak berpengaruh. Maka dapat disimpulkan bahwa konversi lahan pertanian sangat berpengaruh terhadap produktivitas pertanian di Kecamatan Sekarbela.

\section{d. Pendapatan}

Berdasarkan hasil survey menunjukkan bahwa 24 persen responden menjawab < Rp 1.000.000, dan 36 persen responden menjawab > Rp 1.000.000 - Rp 5.000.000 . dan 40 persen resonden menjawab Rp 5.000.000 ke atas. Dari hasil wawancara dan analisis data, dapat disimpulkan bahwa dengan adanya konversi lahan pertania menjadi kawasan terbangun berpengaruh terhadap pendapatan masyarakat Kecamatan Sekarbela.

\section{e. Aksesibilitas}

Berdasarkan hasil survey menunjukkan bahwa 100 persen responden menjawab berpengaruh. Maka dapat disimpulkan bahwa konversi lahan pertanian menjadi kawasan terbangun berpengaruh terhadap aksesibilitas di Kecamatan Sekarbela.

\section{f. Faktor demografi}

Di Kecamatan Sekarbela masyarakatnya menunjukkan kecenderungan memilih tinggal pada wilayah yang memiliki kedekatan dengan fasilitas - fasilitas pelayanan, seperti dekat dengan kawasan perdagangan, perkantoran dan fasilitas umum lainnya.. 
| 104Emi Salmah, Tity Yuniarti, Tuti Handayani/Analisis Pengalihan Fungsi Lahan...

Dari hasil survey menunjukkan bahwa Kelurahan Kekalik Jaya adalah kelurahan terpadat dengan luas wilayah hanya $1,352 \mathrm{Km}^{2}$ dengan kepadatan penduduk $13.734 \mathrm{jiwa} / \mathrm{Km}^{2}$. Sedangkan Kelurahan Jempong Baru kepadatan penduduknya terendah yaitu 3.171 jiwa / $\mathrm{Km}^{2}$ dengan luas wilayah 4,662 $\mathrm{Km}^{2}$.

Berdasarkan hasil analisis Tabel silang, yang mempengaruhi konversi lahan pertanian menjadi kawasan terbangun di Kecamatan Sekarbelaa di adalah faktor hukum, faktor fisik, faktor sosial ekonomi, dan faktor demografi.

\section{Pengaruh konversi lahan pertanian menjadi kawasan terbangun terhadap perekonomian masyarakat.}

Untuk rumusan masalah tentang pengaruh konversi lahan pertanian menjadi kawasan terbangun terhadap perekonomian masyarakat dapat dijelaskan sebagai berikut :

\section{Harga lahan}

Harga lahan pertanian di Kecamatan Sekarbela mengalami peningkatan setiap tahunnya dan penduduk yang memiliki lahan pertanian mereka cenderung untuk menjual tanah mereka.Hal ini dapat dilihat dari meningkatnya harga lahan dari Rp 5.000.000/are dan akibat adanya konversi lahan pertanian kini berubah dan harganya bervariasi dari Rp80.000.000 sampai dengan Rp 175.000.000 /are.Dan para pemilik lahan bisanya melakukan pengkaplingan.

Berdasarkan hasil survey dan wawancara dengan beberapa responden dapat dijelaskan bahwa harga lahan memiliki keterkaitan artinya hubungan antara pengguna lahan dan harga lahan saling terkait. Dengan demikian harga lahan menjadi faktor utama dalam pengaruh konversi lahan pertanian pada kawasan terbangun terhadap perekonomian masyarakat, meskipun harga lahan setiap tahunnya terus meningkat, namun peminatnya masih terus bertambah seiring dengan pertumbuhan ekonomi dan infrastruktur kota.

Konversi lahan tersebut juga mengakibatkan bertambahnya jumlah kepemilikan akan lahan. Selain itu dengan konversi lahan sangat mempengaruhi harga akan lahan, namun kebutuhan akan lahan tidak pernah menurun, karena permintaan akan lahan terus meningkat. Dengan bertambahnya permintaan akan lahan maka harga lahan tersebut malah semakin meningkat, seperti pada tahun 2012 harga lahan yang ada di Karang Pula berkisar Rp 5.000.000,-/ are, namun dengan adanya konversi lahan maka semakin meningkat sampai Rp 
175..000.000,-/ are Tahun 2017. Hal tersebut ditunjang dengan adanya prasarana dan sarana yang ada, seperti jaringan jalan yang beraspal, listrik dan air PDAM. Sedangkan sarana lokasi tersebut dekat dengan daerah perkantoran, perdangangan dan sarana pendidikan.

\section{Mata pencaharian}

Mata pencaharian di Kecamatan Sekarbela pada umumnya adalah pedagang/ wiraswasta serta pegawai/PNS, sedangkan untuk petani yang menggarap lahan pertanian di Kecamatan Sekarbela adalah pemilik lahan sendiri selain itu ada sebagian pemilik lahan yang menggunakan jasa petani penggarap.

Berdasarkan hasil survey dan wawacara dengan responden dapat dilihat bahwa mata pencaharian memiliki keterkaitan artinya hubungan antara pengguna lahan dan mata pencaharian saling terkait. Konversi lahan pertanian, menyebabkan sempitnya lahan pertanian akibatnya hasil panen pertanian mengalami penurunan sedangkan peningkatan akan pemenuhan kebutahan masyarakat semakin tinggi sehingga terjadinya peralihan profesi.

Terjadinya peralihan profesi mengakibatkan terbentuknya lapangan pekerjaan yang baru yaitu dari bermatapencaharian sebagai petani beralih menjadi tukang ojek, buruh bangunan, buruh pasar, tukang tambal ban, tukang kayu (pengerajin kayu), bahkan sampai pedagang asongan. Hal tersebut juga dapat meningkatkan pendapatan.Dengan demikian mata pencaharian menjadi faktor utama dalam pengaruh konversi lahan pertanian terhadap kawasan terbangun terhadap perekonomian masyarakat.

\section{Pendapatan}

Pendapatan tergantung dari apa pekerjaan penduduknya. Berdasarkan hasil survey dan waancara dengan responden diketahui bahwa yang menyatakan pendapatan penduduk ratarata di atas Rp 1.000.000 sebanyak 6 orang atau 24 persen responden, sedangkan yang menyatakan pendapatan penduduk > Rp 2.500.000 - Rp 5.000.000 sebanyak 14 orang atau 56 persen, pendapatan penduduk di atas $\mathrm{Rp}$ $.5,000.000$ sebanyak 5 orang atau 20 persen.

Berdasarkan penjelasan di atas, pendapatan memiliki keterkaitan artinya hubungan antara pengguna lahan dan pendapatan saling terkait.Dengan demikian pendapatan menjadi faktor utama dalam pengaruh konversi lahan pertanian terhadap kawasan terbangun 
|106Emi Salmah, Tity Yuniarti, Tuti Handayani/Analisis Pengalihan Fungsi Lahan...

terhadap perekonomian masyarakat. Hal ini dibuktikan dengan meningkatnya pendapatan masyarakat, dulu sebagai petani, yang pendapatannya tergantung dari hasil panen pertanian, yang rata-rata panennya 2 atau 3 kali dalam setahun, sedangkan pemenuhan akan kebutuhan semakin meningkat, dengan adanya konversi lahan yang membuat terjadinya pergeseran pemanfaatan lahan pertanian yang mengakibatkan terjadinya peralihan profesi/ mata pencaharian. Seperti tukang ojek, buruh pasar, buruh bangunan, tukang tambal ban dan pengerajin kayu, yang dahulu pendapatannya tergantung pada waktu panen, sekarang mereka dapat memperoleh pendapatan perhari dengan jumlah yang lumayan untuk memenuhi kebutuhan mereka.

\section{Produktivitas pertanian}

Produktivitas pertanian di Kecamatan Sekarbela mengalami penurunan setiap tahunnya hal ini terjadi akibat semakin sempitnya lahan pertanian yang akan dikelolah oleh petani. Di Kecamatan Sekarbela untuk pertaniannya terdapat beberapa jenis tanaman pangan yang diusahakan yaitu padi, jagung dan kacang tanah.

Berdasarkan hasil survey dan wawancara dengan responden bahwa produktivitas pertanian memiliki keterkaitan dengan penggunaan lahan.Dengan demikian produktivitas pertanian menjadi faktor utama dalam mempengaruhi konversi lahan pertanian terhadap perekonomian masyarakat. Hal ini disebabkan akan berkurangnya hasil panen pertanian, dengan adanya konversi lahan. Penyempitan lahan pertanian membuat pendapatan petani menurun dan pemenuhan kebutuhan semakin meningkat maka banyak para petani mencari alternatif pekerjaan lain. Penurunan produktivitas pertanian juga disebabkan karena banyak petani yang tidak mampu lagi mengelolah lahan pertaniannya yang disebabkan oleh konversi lahan.

Jadi, berdasarkan analisis data, dapat diketahui bahwa pengaruh konversi lahan pertanian menjadi kawasan terbangun ditinjau dari perekonomian masyarakat, mempunyai pengaruh pada harga lahan, mata pencaharian, pendapatan serta produktivitas pertanian

Mata pencaharian diketahui paling besar pengaruhnya karena mata pencaharian dapat mempengaruhi variabel-variabel lainnya, seperti pendapatan masyarakat karena pendapatan masyarakat tergantung dari apa jenis pekerjaannya, selain itu diketahui pula bahwa dengan adanya 


$\begin{array}{lll}\text { konversi lahan pertanian menjadi } & \text { setelah itu pemilik lahan yang baru } \\ \text { kawasan terbangun, yang dahulunya } & \text { pastinya akan melakukan pengalih fungsi } \\ \text { bermata pencaharian hanya sebagai } & \text { lahan pertanian atau menjualnya dengan } \\ \text { petani yang pendapatan mereka } & \text { harga yang lebih tinggi. Oleh karenanya } \\ \text { tergatung dari waktu panen hasil } & \text { para petani garapan akan beralihan } \\ \text { pertanian, tapi sekarang masyarakat } & \text { profesi mata pencaharian ataupun bahkan } \\ \text { dapat memperoleh tidak hanya satu } & \text { kehilangan mata pencaharian. } \\ \text { pekerjaan untuk satu orang saja, bahkan } & \text { Konversi lahan pertanian menjadi } \\ \text { untuk satu orang dapat memperoleh mata } & \text { kawasan terbangun, mengakibatkan } \\ \text { pencaharian lebih dari satu sumber. } & \text { produktivitas hasil pertanian mengalami } \\ \text { Dengan adanya konversi lahan } & \text { penurunan, karena aktifitas petani akan } \\ \text { pertanian menjadi kawasan terbangun } & \text { mengalami penurunan, hal ini disebabkan } \\ \text { maka harga lahan akan mengalami } & \text { akan berkurangnya lahan pertanian dan } \\ \text { peningkatan, sehingga banyak para } & \text { banyaknya petani yang melakukan } \\ \text { pemilik lahan pertanian yang tertarik } & \text { peralihan mata pencaharian. }\end{array}$
untuk menjual lahan pertanian dan

\section{KESIMPULAN DAN SARAN}

\section{Kesimpulan}

Berdasarkan perumusan masalah yang sebelumnya, dapat ditarik kesimpulan bahwa :

1. Penyebab terjadinya konversi lahan pertanian menjadi kawasan terbangun di Kecamatan Sekarbera, Kota Mataram adalah :faktor hukum, faktorfisik,faktor social ekonomi dan faktor demografi

2. Konversi lahan pertanian menjadi kawasan terbangun terhadap perekonomian masyarakat Kecamatan Sekarbela, Kota
Mataram, mempengaruhi :harga lahan, mata pencaharian, pendapatan, dan produktivitas pertanian. Dari ke empat faktor tersebut maka faktor harga lahan, mata pencaharian, pendapatan dan produktivitas pertanian menjadi faktor yang paling signifikan mempengaruhi perekonomian masyarakat .

\section{Saran - Saran}

Melihat hasil pembahasan yang ada, penulisan ini masih banyak memiliki keterbatasan dan kekurangan dari berbagai segi. Beberapa hal yang mungkin 
|108Emi Salmah, Tity Yuniarti, Tuti Handayani/Analisis Pengalihan Fungsi Lahan...

dapat menjadi rekomendasi dari hasil

penelitian yang dilakukan adalah :

1. Kepada pemerintah Kota Mataram, Peningkatan pengawasan terhadap penggunaan lahan untuk permukiman

di Kecamatan Sekarbela, agar tidak terjadi permukiman yang padat di salah satu lingkungan sehingga permukiman tiap lingkungan merata.

2. Kepada masyarakat Kecamatan

Sekarbela Kota Mataram diperlukan adanya partisipasi masyarakat dalam penyediaan atau pembangunan infrastruktur yang akan dijadikan pengembangan permukiman.

3. Kepada peneliti selanjutnya untuk mengkaji penentuan lokasi lahan pengembangan permukiman dengan berorientasi pada kondisi budaya masyarakat dan penentian arah pengembangan Kecamatan Sekarbela, Kota Mataram.

\section{DAFTAR PUSTAKA}

BPS kota mataram. 2016, Kota Mataram Dalam Angka. Mataram.2016

Haeruddin,1997, Analisis perubahan penggunaan lahan di kecamatan Parangloe kabupaten Gowa.Tesis pascasarjana Universitas Hasanuddin. Makasar.1997

Hadi sahari yunus, 2008, Manajemen Kota.Yogyakarta: Pustaka Pelajar,2008

Malville,2000, Perencanaan Kota Komprehensip, Pengantar Dan Penjelasan. Gadjah Mada University Press.

RB.Wicaksono, 2005,Konversi Lahan Sawah Ke Non Pertanian Dalam Perkembangan Kota Nganjuk Dan Pengaruhnya Terhadap Perubahan Mata Pencaharian Dan Pendapatan Petani. Malang

BPS Kota Mataram.2016, Kecamatan Sekarbela Dalam Angka, Mataram 2016 